\title{
UJI ANTI INFLAMASI SECARA TOPIKAL EKSTRAK ETANOL UMBI SARANG SEMUT (Myrmecodia tuberosa Jack) PADA MENCIT PUTIH JANTAN
}

\author{
Muhammad Islamoyo ${ }^{1}$, Yufri Aldi ${ }^{2}$, Surya Nelis ${ }^{1}$ \\ ${ }^{1}$ Faculty of Dentistry Andalas University \\ ${ }^{2}$ Departemen of Oral Medicine Faculty of Dentistry Andalas University
}

\begin{abstract}
Inflammation is a tissue response towards damaging physical or chemical stimulations. One local sign of inflammation is edema (tumor). Usage of natural herbal medicine has become an alternative way to prevent inflammation. The extract of umbi sarang semut (Myrmecodia tuberosa Jack) has antiinflammation, anti-bacterial and antioxidant properties. This study is to determine the anti-inflammation effect of the topical application of Myrmecodia tuberosa Jack ethanol extract. This study used 28 white male rats previously induced with carragenin $2 \% \mathrm{~b} / \mathrm{v} \quad 0,5 \mathrm{ml}$ and divided into 4 treatment groups. Groups 1,2 dan 3 were given the ethanol extract with a concentration of 0,5\%; 1\%; $2 \%$ respectively after induction and on 24, 48 and 72 hours after the first application. Group 4 was the untreated control group. Each treatment group were extracted for their inflammation exudate fluid from their backs using a $1 \mathrm{ml}$ syringe. Edema fluid volume was measured. The results showed a decrease of edema fluid volume on all treatment groups. Statistical data analysis showed a significant difference between group 2 and the negative control; also between group 3 and the negative control. In conclusion, the topical ethanol extract of Myrmecodia tuberosa Jack can reduce inflammation reactions.
\end{abstract}

Keywords: Myrmecodia tuberosa Jack, anti-inflammation, topical, edema fluid volume

Affiliasi penulis : 1. Fakultas Kedokteran Gigi Universitas Andalas. 2. Fakultas Farmasi Universitas Andalas. Korespondensi: Muhammad Islamoyo Rewando Tutan email:moyobp@yahoo.co.id Telp: 085274232343

\section{PENDAHULUAN}

Inflamasi merupakan respon

protektif setempat yang ditimbulkan oleh cedera atau kerusakan jaringan, yang berfungsi menghancurkan, mengurangi, atau mengurung (sekuester) agen pencedera maupun jaringan yang cedera. Keadaan akut ditandai oleh tanda klasik yaitu nyeri (dolor), panas (kalor), kemerahan (rubor), bengkak (tumor), dan hilangnya fungsi (fungsiolesa). Secara histologis, menyangkut rangkaian kejadian yang mencakup dilatasi arteriol, kapiler dan venula, disertai peningkatan permeabilitas dan aliran darah, eksudasi cairan, termasuk protein plasma dan migrasi leukositik ke dalam fokus peinflamasian ${ }^{1}$.

Reaksi inflamasi sering ditemukan pada masyarakat. Inflamasi dapat terjadi pada bagian tubuh seperti pada rongga mulut. Inflamasi pada rongga mulut dapat berupa gingivitis, stomatitis, ulkus dan trauma pasca bedah. Rasa sakit dari proses inflamasi menjadi penyebab terganggunya aktivitas sehari-hari ${ }^{2,3}$. Inflamasi terbagi menjadi dua pola dasar yaitu inflamasi akut dan inflamasi kronik. Inflamasi akut adalah 
inflamasi yang berlangsung relatif singkat, dari beberapa menit sampai beberapa hari, dan ditandai dengan eksudasi cairan dan protein plasma serta akumulasi leukosit neutrofilik yang menonjol. Inflamasi kronik berlangsung lebih lama (berhari-hari sampai bertahun tahun) dan ditandai khas dengan influks limfosit dan makrofag dan disertai dengan proliferasi pembuluh darah dan pembentukan jaringan parut ${ }^{4}$ Pada gusi dan rongga mulut, proses inflamasi dapat terjadi karena beberapa faktor, seperti terinfeksi bakteri dan trauma pasca bedah. Inflamasi pada gusi dan rongga mulut biasanya di awali dengan kebersihan rongga mulut yang tidak terjaga. Kebersihan rongga mulut yang tidak terjaga menjadi tempat yang subur untuk perkembangan bakteri.

Bakteri dan produknya melakukan invasi ke dalam epitel sulkus gingiva, sehingga dengan teraktivasinya epitel maka akan terjadi pelepasan mediator-mediator inflamasi. Trauma menjadi salah satu penyebab terjadinya inflamasi, trauma itu bisa terjadi karena kesalahan saat menyikat gigi, kesalahan operator pada saat tindakan, dan trauma yang terjadi pasca pembedahan $^{5,6,7}$

Untuk mencegah atau mengatasi reaksi inflamasi seperti trauma pasca pembedahan dapat digunakan obat kimia, yaitu golongan NSAID dan golongan steroid. Kedua golongan obat tersebut mempunyai efek samping yang tidak diharapkan dan menimbulkan penyakit baru. Efek samping sistemik (peroral) seperti tukak lambung, gangguan ginjal, kardiovaskuler dan efek samping topikal seperti atropi pada mukosa, kandidiasis sekunder, mual dan lain sebagainya. Untuk itu dicari obat lain yang tidak memiliki efek samping yang berasal dari tumbuhan dan masyarakat telah menggunakannya secara turun temurun ${ }^{8,9,10}$.

Indonesia merupakan negara yang memiliki kekayaan keanekaragaman hayati tertinggi kedua setelah Brasil. Jumlah spesiesnya diperkirakan pada takson tumbuhan berbunga yang terdapat di Indonesia sebesar $10 \%$ atau sebanyak 25.000 jenis, sedangkan di dunia terdapat sebanyak 250.000 jenis. Diantara jenis tumbuhan berbunga yang terdapat di Indonesia, 1.845 jenis diketahui berkhasiat sebagai obat yang telah dipergunakan dalam pengobatan tradisional secara turuntemurun oleh berbagai etnis di Indonesia ${ }^{11}$

Tumbuhan sarang semut merupakan salah satu tumbuhan potensial yang tumbuh dengan beraneka ragam spesies dengan bentuk dan warna daging yang bervariasi. Tumbuhan sarang semut (famili Rubiaceae) pertama kali ditemukan di daerah Papua, spesies sarang semut yang sering di temukan di daerah Papua adalah Myrmecodia pendens. Penggunaan tumbuhan sarang semut di papua telah 
terbukti secara empiris berkhasiat untuk menyembuhkan berbagai macam penyakit secara alami dan relatif aman.

Tumbuhan sarang semut secara turun temurun telah digunakan sebagai obat oleh masyarakat pedalaman, khususnya sebagai obat penyembuh inflamasi, menguatkan imunitas tubuh dan mengatasi nyeri otot. Bahagian yang digunakan adalah umbinya $^{11}$. Tumbuhan sarang semut adalah tumbuhan epifit. Sarang semut adalah anggota Rubiaceae family dengan 5 genus, namun hanya 2 jenis tumbuhan yang memiliki hubungan dengan semut, yairu adalah Myrmecodia dan hypnophytum.12,13. Secara ekologi, tumbuhan sarang semut tersebar dari hutan hutan bakau dan pohon pohon pohon di pinggir pantai.

Tumbuhan sarang semut juga telah diketahui banyak tumbuh di kepulauan Mentawai. Tumbuhan sarang semut yang ada di Mentawai adalah Myrmecodia tuberosa Jack. Masyarakat sekitar telah menggunakan tumbuhan sarang semut sebagai obat demam, alergi pada kulit dan meningkatkan daya tahan tubuh dengan cara menghaluskan umbi dari tumbuhan sarang semut kemudian merebusnya lalu meminumnya ${ }^{14,15}$.

Pengobatan tradisional dengan sarang semut tidak membutuhkan banyak biaya dan memiliki efek samping yang minimal. Subroto \& Saputro (2006), menyatakan bahwa Sarang Semut mempunyai senyawa aktif seperti flavonoid, tanin, polifenol, tokoferol, magnesium, kalsium, besi, fosfor, natrium, dan seng. Senyawa aktif yang terkandung dalam sarang semut memiliki banyak khasiat, yaitu sebagai antimikroba, antiinflamasi, antioksidan, antidiabetes dan antikanker ${ }^{15,16}$.

Penelitian mengenai umbi sarang semut secara subkutan menunjukan bahwa ekstrak etanol Myrmecodia tuberosa Jack dapat menghambat reaksi anafilaksis kutan aktif pada mencit putih betina ${ }^{17}$. Ekstrak etanol tumbuhan umbi sarang semut juga dapat menghambat pertumbuhan Candida albicans, Eschericia coli, dan Staphylococcus aureus ${ }^{18}$. Pemberian ekstrak air tumbuhan sarang semut terhadap mencit (mus muculus) secara peroral juga mampu mengatasi diare dan meningkatkan konsistensi feses ${ }^{19}$. Penelitian sebelumnya yang dilakukan oleh Kristina (2008) didapatkan hasil bahwa pemberian ektraks etanol $M$. pendens Merr \& perry secara peroral terhadap tikus (Rattus norvegicus L. ) pada dosis $9 \mathrm{mg} / 200 \mathrm{~g} \mathrm{BB}$ teruji mampu menurunkan inflamasi dengan daya anti inflamasi paling optimal sebesar 29,726\% pada lokasi udem yang diinduksi karragenin $1 \%^{20}$.

Inflamasi akut dapat dibuat dengan berbagai metode yaitu metode penginduksian udem buatan, dan metode 
pembentukan eritema (respon kemerahan), sedangkan inflamasi kronis dibuat dengan metode pembentukan granuloma. Pada penelitian ini akan digunakan metode penginduksian udem buatan.

Metode ini dipilih karena tidak membutuhkan waktu yang lama dan pengukuran udem dapat dilakukan dengan akurat serta mudah dilakukan (praktis). Pengamatannya dapat dilihat dari kemampuan obat anti inflamasi mengurangi volume udem yang di induksi pada mencit 21,22 .

Penelitian tentang uji anti inflamasi terhadap tumbuhan sarang semut (Myrmecodia tuberosa Jack) secara topikal belum ada. Berdasarkan latar belakang di atas maka penulis tertarik untuk melakukan penelitian terhadap umbi dari tumbuhan sarang semut (Myrmecodia tuberosa Jack) terhadap reaksi inflamasi dengan rute pemberian secara topikal. Sediaan yang diujikan adalah hasil ekstraksi dari umbi sarang semut dan dibuat dalam bentuk salep.

\section{METODE}

Metode penelitian ini adalah eksperimental dengan menggunakan rancangan penelitian post test with control group. Besar sampel dihitung denganrumus Frederer dan didapatkan banyak sampel untuk semua perlakuan yaitu ${ }^{24}$. Untuk mengantisipasi hilangnya unit eksperimen, digunakan rumus koreksi dan didapatkan total sampel untuk semua perlakuan yaitu 28. Alat yang digunakan pada penelitian adalah kandang hewan botol maserasi, alat destilasi vakum, rotary evaporator, spuit 5 $\mathrm{ml}$, spuit $1 \mathrm{ml}$, gunting bedah, timbangan, lumpang dan stamfer, neraca analitik, alat cukur, handschoen, masker, spidol Gelas ukur. Bahan yang digunakan pada penelitian adalah tumbuhan sarang semu, metanol, vaselin flava, carragenin, oleum sesami, krim perontok bulu, krust ekstrak.

Prosedur penelitian dimulai dari pemeliharaan dan perlakuan hewan percobaan. Semua mencit yang akan diberikan perlakuan sebelumnya diadaptasikan selama 7 hari dengan lingkungannya. Selama adaptasi mencit ditimbang diawal dan akhir dari adaptasi. Mencit dibagi kedalam 4 kelompok, dengan masing-masing kelompok terdiri dari 7 ekor mencit. Setiap kelompok diberi perlakuan yang berbeda, dengan rincian, Kelompok 1 diolesi ekstrak etanol dari tumbuhan sarang semut sediaan salep dengan konsentrasi dosis $0,5 \%$, Kelompok 2 diolesi ekstrak etanol dari tumbuhan sarang semut sediaan salep dengan konsentrasi dosis $1 \%$, Kelompok 3 diolesi ekstrak etanol dari tumbuhan sarang semut sediaan salep dengan konsentrasi dosis 2\%, Kelompok 4 sebagai kelompok kontrol yang tidak diberi perlakuan

Selama 24 jam sebelum perlakuan mencit dicukur bulu bagian punggungnya, 
dengan luas daerah yang dicukur diameter $3 \mathrm{~cm}$. Mulanya dipotong dengan gunting, selanjutnya untuk menghilangkan bulu yang masih tersisa dioleskan krim perontok bulu, sehingga bulunya betul betul hilang. Bagian punggung yang dicukur disuntikkan dengan udara sebanyak $5 \mathrm{ml}$ secara subkutan sehingga terbentuk kantong udara dan sekaligus disuntikan juga $0,1 \mathrm{ml}$ carragenin $2 \% \mathrm{~b} / \mathrm{v}$ dalam oleum sesami. Setelah 24 jam kantong udara terbentuk, dihisap udaranya dengan jarum suntik $5 \mathrm{ml}$ sehingga kantong udara tersebut jadi kempes.Selanjutnya ditambahkan larutan carragenin $2 \% \mathrm{~b} / \mathrm{v}$ dalam oleum sesami sebanyak 0,5 ml pada tempat yang ada kantong udara tersebut.

Sediaan uji dalam salep diberikan dengan cara mengoleskan secara merata pada daerah yang terbentuk kantong udara sebanyak 200 mg, dengan diameter pengolesan $3 \mathrm{~cm}$. Segera setelah pemberian carragenin $2 \% \mathrm{~b} / \mathrm{v}$ dalam oleum sesami sebanyak $0,5 \mathrm{ml}$. Selanjutnya obat diberikan lagi setelah 24,48, dan 72 jam setelah pemberian pertama. Pada kontrol negatif hanya di olesi dengan vaselin flava.

Pada hari ke-4 setelah pmberian obat maka hewan percobaan dikorbankan dan diambil cairan eksudat inflamasi yang terdapat pada bagian punggung tersebut dengan spuit $1 \mathrm{ml}$ dan ditentukan volumenya
Data yang diperoleh dianalisis menggunakan ujiOne Way Annova jika sebaran data normal dan uji Parametric jika sebaran data tidak normal. Analisis data dilanjutkan dengan uji Post Hoc untuk mengetahui perbedaan masing-masing kelompok perlakuan dengan kelompok perlakuan lainnya

\section{HASIL}

Tabel 5.1 Rata-rata volume cairan udem pada semua kelompok uji

\begin{tabular}{lcc}
\hline Kelompok & n & Mean \pm SD \\
& 6 & $0,24 \pm 0,06$ \\
\hline Perlakuan 1 & $0,16-0,31$ \\
Perlakuan 2 & 6 & $0,21 \pm 0,04$ \\
& & $0,18-0,29$ \\
Perlakuan 3 & 6 & $0,16 \pm 0,02$ \\
& & $0,12-0,21$ \\
Kontrol negatif & 6 & $0,31 \pm 0,05$ \\
\hline F & & $0,24-0,38$ \\
\hline
\end{tabular}

Keterangan :

Perlakuan $1=$ konsentrasi dosis $0,5 \%$

Perlakuan $2=$ konsentrasi dosis $1 \%$

Perlakuan $3=$ konsentrasi dosis $2 \%$

Pada tabel 5.1. dapat dilihat rata-rata volume cairan udem tertinggi terdapat pada kelompok kontrol negatif dan rata-rata volume cairan udem terendah terdapat pada kelompok perlakuan 3. 


\subsection{Analisa Bivariat}

Analisis bivariat yang digunakan pada penelitian ini adalah One Way Anova. Uji ini dilakukan untuk membandingkan perbedaan rata-rata jumlah Volume cairan udem pada semua kelompok uji. Sebelum melakukan uji analisis data statistik terlebih dahulu dilakukan uji normalitas untuk masing-masing kelompok sampel dengan menggunakan uji statistik Shapiro-Wilk untuk melihat data penelitian terdistribusi normal atau tidak. Uji normalitas menunjukkan nilai $\mathrm{p}>0,05$. Hasil uji normalitas data dapat dilihat pada tabel 5.2.

Tabel 5.2 Hasil uji normalitas data Shapiro-Wilk

\begin{tabular}{lll}
\hline & n & Sig \\
\hline Perlakuan 1 & 6 & 0,20 \\
Perlakuan 2 & 6 & 0,29 \\
Perlakuan 3 & 6 & 0,66 \\
Kontrol negatif & 6 & 0,72 \\
\hline
\end{tabular}

Tabel 5.2 menunjukkan bahwa distribusi semua datamemiliki sebaran yang normal, sehingga analisis data One Way Anova dapat dilakukan. Uji homogenitas dilakukan untuk mengetahui variansi antar kelompok-kelompok yang diuji sama atau tidak. Uji homogenitas yang digunakan adalah Levene's test for equality of variance. $\mathrm{Uji}$ homogenitas data menunjukkan $\mathrm{p}>0,05$, sehingga data memiliki varian yang sama atau homogen.
Hasil uji homogenitas Levene's test menunjukkan data memiliki varian yang sama atau homogen $(\mathrm{p}>0,05)$.

Tabel. 5.3 Uji One Way Anova

\begin{tabular}{llllll}
\hline & $\begin{array}{l}\text { Sum of } \\
\text { Squares }\end{array}$ & df & $\begin{array}{l}\text { Mean } \\
\text { Square }\end{array}$ & F & Sig \\
\hline $\begin{array}{l}\text { Between } \\
\text { Groups }\end{array}$ & 0,06 & 3 & 0,02 & 9,82 & 0,00 \\
\hline Within & 0,04 & 20 & 0,002 & & \\
Groups & & & & & \\
\hline Total & 0,11 & & & & \\
\end{tabular}

Pada hasil uji One Way Anova didapatkan hasil $\mathrm{p}=0,0005$ dimana $\mathrm{p}<$ 0,05 bermakna bahwa semua kelompok perlakuan mempunyai perbedaan yang signifikan. Setelah hasil One Way Anova didapat dilakukan uji Post Hoc test untuk mengetahui kelompok mana saja yang berhubungan signifikan. Hasil uji Post Hoc test dapat dilihat pada tabel ${ }^{5.4}$

Tabel. 5.4 Uji statistik perbedaan rata-rata volume cairan udem pada masing-masing kelompok

\begin{tabular}{ccccc}
\hline $\begin{array}{c}\text { Kelom } \\
\text { pok } \\
\begin{array}{c}\text { Perlak } \\
\text { uan }\end{array}\end{array}$ & $\begin{array}{c}\text { p } \\
\text { uan 1 } \\
\text { uan }\end{array}$ & $\begin{array}{c}\text { p } \\
\text { uan 2 }\end{array}$ & $\begin{array}{c}\text { p } \\
\text { Perlak } \\
\text { uan 3 }\end{array}$ & $\begin{array}{c}\text { p } \\
\text { kont } \\
\text { rol } \\
\text { nega } \\
\text { tif }\end{array}$ \\
\hline $\begin{array}{c}\text { Perlaku } \\
\text { an 1 }\end{array}$ & - & 1,00 & 0,05 & 0,14 \\
\hline $\begin{array}{c}\text { Perlaku } \\
\text { an 2 }\end{array}$ & - & 0,5 & 0,01 \\
\hline $\begin{array}{c}\text { Perlaku } \\
\text { an 3 }\end{array}$ & & & \\
\hline
\end{tabular}


Tabel 5.4 menunjukkan bahwa perbedaan yang signifikan rata-rata jumlah volume cairan udem hanya terdapat antara kelompok perlakuan 2 dengan kontrol negatif dan perlakuan 3 dengan kontrol negatif $(\mathrm{p}<0,05)$ sedangkan yang lainnya tidak menunjukan perbedaan yang signifikan.

\section{PEMBAHASAN}

Penelitian ini dilakukan untuk mengetahui efek anti inflamasi dari tumbuhan umbi sarang semut (Myrmecodia tuberosa Jack) secara topikal. Sampel pada penelitian ini adalah mencit putih jantan berjumlah 28 ekor yang dibagi menjadi 4 perlakuan. Tumbuhan yang digunakan pada penelitian ini adalah tumbuhan umbi sarang semut (Myrmecodia tuberosa Jack). Tumbuhan umbi sarang semut ini didapatkan dari kepulauan Mentawai. Hewan percobaan yang digunakan adalah mencit putih jantan. Mencit putih jantan dipilih karena mudah didapat, penanganannya mudah, dan fisiologisnya mirip dengan manusia.Untuk mengurangi penyimpangan hasil penelitian maka dipilih mencit dengan jenis kelamin, usia, dan berat badan yang relatif sama.

Pada analisa univariat didapatkan hasil bahwa ekstrak etanol tumbuhan umbi sarang semut dengan pemberian secara topikal dapat menekan reaksi inflamasi, hal ini dapat dilihat dari rata-rata volume cairan udem setiap kelompok perlakuan lebih rendah dari kelompok kontrol. Hasil ini sesuai dengan penelitian Kristina (2008) bahwa pemberian ekstrak etanol tumbuhan umbi sarang semut secara per oral mampu menekan rekasi inflamasi ${ }^{20}$. Berdasarkan uji One Way Anova terdapat perbedaan yang bermakna pada setiap kelompok. Perbedaan ini disebabkan karena konsentrasi dosis masing-masing dari perlakuan berbeda, sehingga mempengaruhi volume cairan udem pada masingmasing kelompok perlakuan.

$$
\text { Berdasarkan uji Post Hoc }
$$

Bonferroni diperoleh perbedaan yang signifikan volume cairan udem antara kelompok perlakuan 2 dengan kontrol negatif dan perlakuan 3 dengan kontrol negatif, sedangkan kelompok perlakuan 1 tidak terdapat perbedaan yang bermakna terhadap kelompok kontrol negatif. Hal ini disebabkan oleh konsentrasi dosis yang dimiliki kelompok perlakuan 1 lebih rendah dari kelompok perlakuan 2 dan 3 sehingga tidak menekan reaksi inflamasi secara efektif.

Hasil uji Post Hoc juga menunjukan bahwa kelompok perlakuan 1 tidak terdapat perbedaan bermakna dengan kelompok perlakuan 2. Hal yang sama juga ditunjukan oleh kelompok perlakuan 2 dengan kelompok perlakuan 3, yaitu tidak terdapat perbedaan bermakna dari 2 kelompok perlakuan tersebut. Hasil yang berbeda di tunjukan oleh kelompok perlakuan 1 
dengan kelompok perlakuan 3, yaitu terdapat perbedaan yang bermakna dari 2 kelompok tersebut. Hal ini disebabkan oleh rentangan perbedaan konsentrasi dosis yang di miliki kelompok perlakuan $1(0,5 \%)$ dengan kelompok perlakuan 3 (2\%) cukup jauh. Perbedaan konsentrasi tersebut mengakibatkan perbedaan senyawa flavonoid yang terkandung di dalam dosis tersebut. Semakin banyak senyawa flavonoid yang terkandung dalam konsentrasi dosis, semakin kuat anti inflamasinya, karena flavonoid dapat menghambat mediatormediator inflamasi seperti asam arakidonat, menghambat enzim lipooksigenase (COX) dan siklooksigenase (LO), mengurangi akumulasi leukosit dan mengimbangi reaksi radikal bebas ${ }^{23,20,24}$.

Konsentrasi dosis pada penelitian ini ditentukan dengan uji pendahuluan. Pada uji pendahuluan dosis yang digunakan adalah $0,5 \% ; 1 \% ; 2 \%$;. Ketiga dosis tersebut memberikan efek pada reaksi inflamasi sehingga ketiga dosis tersebut dijadikan dosis tetap pada penelitian ini. Sediaan uji dibuat dalam bentuk sediaan salep dengan vaseline flava sebagai zat pembawanya.

Berdasarkan penelitian ini, ekstrak etanoltumbuhan umbi sarang semut (Myrmecodia tuberosa Jack) memiliki aktifitas sebagai anti inflamasi secara topikal, dengan bertambahnya konsentrasi semakin bertambah pula aktifitas anti inflamasinya.

Keterbatasan dalam penelitian ini adalah proses penyuntikan carraagenin pada punggung mencit. Proses penyuntikan carragenin terganggukarena tipisnya kulit mencit dan reaksi mencit saat akan disuntik sehingga mempengaruhi terbentuknya udem.

\section{KESIMPULAN}

Setelah dilakukan penelitian terhadap uji anti inflamasi secara topikal ekstrak etanol umbi sarang semut (Myrmecodia tuberosa Jack) dilihat dari volume cairan udem, maka diperoleh hasil sebagai berikut :

1. Pemberian ekstrak etanol umbi sarang semut (Myrmecodia tuberosa Jack) secara topikal dapat menekan terjadinya reaksi inflamasi.

2. Pemberian ekstrak etanol umbi sarang semut (Myrmecodia tuberosa Jack) secara topikal dapat menekan terjadinya reaksi inflamasi dengan parameter penurunan volume cairan udem menunjukan perbedaan yang bermakna $(p<0,05)$

3. Efek anti inflamasi yang bekerja paling maksimal diberikan oleh konsentrasi 2\% dengan jumlah volume cairan udem paling sedikit.

\section{KEPUSTAKAAN}

1. Dorland . Kamus Kedokteran Dorland, Alih bahasa : Retna Neary Elseria, dkk. Judul 
Asli Dorland's Illustrated Medical

Dictionary . Jakarta : EGC 2010.

2. Wijayanti P.M. Kebersihan Rongga Mulut dan Gigi Pasien Stroke. Departemen Ilmu Kesehatan Masyarakat, Fakultas Kedokteran Universitas Islam Indonesia, Yogyakarta, Indonesia. 2011: 37-40

3. Arbie R. Penanggulangan Rasa Sakit Dengan Analgetika Dalam Bentuk Obat Bebas. Digitized by USU digital library 2003.

4. Robbins, Stanley L, dkk. Buka Ajar Patologi Robbins. Ed ke7. Jakarta : Penerbit Buku Kedokteran EGC. 2004 ; 1

5. Wijayanti P.M dan Ismail S. Correlation between Periodontitis, Asterosklerosis and Acute Iskemik Stroce. Departemen Ilmu Kesehatan Masyarakat Fakultas Kedokteran Universitas Islam Indonesia. Mutiara Medika. 2008 ; 8 (2) : 120-128

6. Lahama L, dkk. Angka Kejadian Stomatitis yang Diduga Sebagai Denture Stomatitis Pada Pengguna Gigi Tiruan di Kelurahan Batu Kota Manado. Jurnal Ilmiah Farmasi Universitas

1. Sam Ratulangi. 2015 ; 4 (4)

7. Bakar Abu.Kedokteran Gigi Klinis.Quantum. Yogyakarta. 2012 : P. 11121

8. Roberts, L.J dan J.D. Morrow. Senyawa Analgesik-antipiretik dan Antiinflamasi Serta Obat-Obat yang Digunakan dalam Penanganan Pirai, dalam Dasar Farmakologi Terapi, Joel, G, Hardman dan Lee, E, limbird (editor). Ed

9. Penerbit Buku Kedokteran EGC. 2002 :2

10. Lelo A, dkk. Penggunaan Anti-Inflamasi Non- Steroid Yang Rasional Pada PenanggulanganNyeri Rematik. Bagian Farmakologi dan Terapeutik Universitas
Sumatera Utara. e-USU Repository Universitas Sumatera Utara 2004.

11. Savage, NW. Topical Steroid in Dental Practice, 2005. Aust Dent J ; Vol 50 Suppl

2. $2: 40-44$

12. Dirgantara S, dkk. Studi Botani dan Fitokimia Tiga Spesies Tumbuhan Sarang Semut Asal

3. Kabupaten Merauke, Provinsi Papua. Jurnal Farmasi Sains Dan Terapan. 2015 ; 2 (1) : 20-22

13. Ahmad I, dan Risna L. Isolasi Antioksidan Tumbuhan Sarang Semut (Myrmecodia pendens Merr \& Perry) Asal Papua. J. Trop. Pharm. Chem. 2011 ; 1 (3) : 199-204.

14. Soeksmanto A, dkk. Anticancer Activity test for Extracts of Sarang Semut Plant (Myrmecodya pendens) to HeLa and MCM-B2 Cells. Pakistas Journal of Biological Sciences,2009. 13(3): 148-151.

15. Hamidah S, dan Budi S. Kadar Ekstraktif Sarang Semut (Myrmecodia sp) dari Kabupaten Barito Timur. Jurnal Hutan Tropis.2011; 12 (31)

16. Subroto, M.A. dan H. Saputro. Gempur penyakit dengan sarang semut. Penerbit Swadaya, Jakarta 2006.

17. Ahkam, M S. Obat alternatif : sarang semut penakluk penyakit maut. Diperoleh dari http://www.sarangsemut.50webs.com/obat \%20 alternatif.htm 2008.

18. Salam T. Uji Efek Anafilaksis Kutan Aktif Fraksi Etil Asetat Sarang Semut (Myrmecodia tuberosa Jack) Terhadap Mencit Putih Betina. Fakultas Farmasi Universitas Andalas, 2016.

19. Efendi, Y.N dan T. Hertiani. Potensi Antimikroba Ekstrak Etanol Sarang Semut (Myrmecodia tuberosa Jack) Terhadap Candida Albicans, Escherichia Coli dan 
Staphylococcus aureus. Traditional

Medicine Journal. 2013 ; 18(1). P. 53-58.

20. Defrin, D. P., Rahimah, S. B., Yuniarti, L. Efek Anti Diare Ekstrak Air Umbi Sarang Semut (Myrmecodia pendens) Pada Mencit Putih (Mus musculus). Prosding SnaPP. Ed Eksakta. 2010 ; 70(18) : 2089-3582.

21. Kristina D. Efek Antiinflamasi Ekstrak Etanol Umbi Sarang Semut (Myrmecodia pendens

4. Merr. \& Perry) Pada Tikus Putih (Rattus norvegicus L.). Jurusan Biologi FMIPA UNS

5. Surakarta. 2008.

22. Gryglewski, R.J., some Experimental Models for the Study of Inflamation and AntiInflammatory

6. Drugs, in I. L. Bonta, J. Thomson, and K. Brune, Inflammation : Mechanism and their impact on therapy, 19-21, Bhirkaueser Verlag Basel, Rotterdam. 1977.

23. Vogel, H. G. Drug discovery and evaluations pharmacological assays. (2th Edition). Germany : Springer-Verlag Berlin Heidelberg. 2002.

24. Tapas AR. DM Sakarkar and RB Kakde. Flavonoids as Nutraceuticals: A Review. Tropical Journal of Pharmaceutical Research. Faculty of Pharmacy, University of Berlin. 2008 ; 7 (3) : 1089-1099.

25. Middleton E, dkk. The Effects of Plant Flavonoid on Mammalian Cells Implications for inflammation, heart disease and Cancer. By the American Society for Pharmacology and Experimental Therapeutics. 2000; 52 : 673-

751. 